\title{
PENYANDANG DISABILITAS DAN UU NOMOR 11 TAHUN 2020 TENTANG CIPTA KERJA
}

\section{PERSONS WITH DISABILITIES AND LAW NUMBER 11 OF 2020 CONCERNING JOB CREATION}

\author{
Bintang Ulya Kharisma \\ Universitas PGRI Madiun \\ Bintangkharisma25@gmail.com \\ Sofyantoro \\ Universitas PGRI Madiun \\ Sofyantoro23@gmail.com
}

\begin{abstract}
Abstrak
Penyandang disabilitas merupakan kelompok minoritas tertinggi di dunia. Jumlah tersebut diperkirakan akan terus bertambah dari tahun ke tahun seiring dengan pertumbuhan jumlah penduduk dunia, bencana alam dan faktor-faktor lainnya. Tujuan penelitian untuk mengetahui hubungan terkait undang-undang cipta kerja yang tidak ramah kaum disabilitas. Metode penelitian yang digunakan yaitu studi pustaka dengan sumber utama yaitu uu no. 11 tahun 2020 tentang cipta kerja. Hasil penelitian ini adalah UU Cipta Kerja justru tidak mendukung pemenuhan hak penyandang disabilitas dalam mendapatkan akomodasi yang layak dalam dunia kerja. UU Cipta Kerja tidak mencantumkan ketentuan kuota $1 \%$ bagi perusahaan swasta dan $2 \%$ bagi BUMN/BUMD dan Pemerintah/Pemerintah Daerah untuk mempekerjakan penyandang Disabilitas dari keseluruhan pegawai, yang saat ini tercantum dalam UU 8 Tahun 2016 tentang Penyandang Disabilitas.
\end{abstract}

\section{Kata Kunci : Disabilitas, Pemerintah, Cipta Kerja}

\begin{abstract}
Persons with disabilities constitute the highest minority group in the world. This number is expected to continue to increase from year to year in line with world population growth, natural disasters and other factors. The purpose of this study is to determine the relationship related to work creation which is not friendly to people with disabilities. The research method used is literature study with the main source, namely the law number 11 of 2020 concerning Job Creation. The result of this research is that the Job Creation Law does not actually support the fulfillment of the rights of persons with disabilities in getting proper accommodation in the world of work. The Job Creation Law does not include a 1\% quota provision for private companies and $2 \%$ for BUMN / BUMD and Government / Local Government to employ persons with disabilities from all employees, which are currently listed in the Law on Persons with Disabilities.
\end{abstract}

Keywords : Disability, Government, Job Creation 


\section{A. Pendahuluan}

Penyandang disabilitas merupakan kelompok minoritas tertinggi di dunia. Jumlah tersebut diperkirakan akan terus bertambah dari tahun ke tahun seiring dengan pertumbuhan jumlah penduduk dunia, bencana alam dan faktor-faktor lainnya ${ }^{1}$. Di Indonesia sendiri bagi para penyandang disabilitas sudah dilindungi dalam UU Nomor 8 Tahun 2016 Tentang Penyandang Disabilitas. Hal ini mengacu kembali kepada konsep dasar Hak Asasi Manusia (HAM) bahwa setiap manusia tanpa terkecuali memiliki hak yang paling mendasar, yaitu HAM yang melekat pada diri manusia secara otomatis, bukan karena diberikan oleh masyarakat atau berdasarkan hukum positif, melainkan semata-mata karena martabatnya sebagai manusia sejak ia berada dalam kandungan sampai akhirnya ia meninggal ${ }^{2}$. Dengan demikian penyandang disabilitas pun

\footnotetext{
${ }^{1}$ United Nations Economic and Social Comission for Asia and the Pacific, "Overview" http://www.unescapsdd.org/disability/overview, diakses tanggal 20 Agustus 2019 pukul 15.20 WIB

${ }^{2}$ Rhona K.M. Smith et al., Hukum Hak Asasi Manusia, cet 1, (Yogyakarta: Pusat Studi Hak Asasi Manusia Universitas Islam Indonesia, 2008), hal. 11.
}

sudah selayaknya menikmati hak-hak mendasar ini seperti manusia lain pada umumnya tanpa ada pengurangan atau pembatasan yang disebabkan oleh keadaan mereka, karena hak-hak itu melekat pada dirinya sebagai makhluk insani ${ }^{3}$.

Disabilitas yang diolah dari hasil SUPAS 2015 meliputi kesulitan melihat, mendengar, menggunakan tangan/jari, mengingat/berkonsentrasi, gangguan perilaku/emosional, berbicara, serta mengurus diri sendiri. Menurut data SUPAS 2015 terdapat 8,56 persen penduduk yang memiliki disabilitas. Jika dilihat pada kesulitan melihat, terdapat 0,13 persen penduduk yang sama sekali tidak bisa melihat, 0,72 persen yang memiliki tingkat kesulitas melihat yang berat, serta 5,51 persen yang sedikit mengalami kesulitan melihat. Persentase penduduk yang mengalami kesulitan mendengar adalah 0,09 persen yang sama sekali tidak mendengar, 0,57 persen yang mengalami banyak kesulitan mendengar serta 2,69 persen yang mengalami sedikit kesulitan mendengar. Persentase penduduk yang mengalami kesulitan berjalan/naik tangga adalah 3,76 persen, sedangkan penduduk yang mengalami kesulitan

\footnotetext{
${ }^{3}$ Ibid.
} 
menggerakkan tangan/jari adalah sebesar 1,31 persen. Penduduk yang mengalami kesulitan mengingat/berkonsentrasi sebesar 2,82 persen, sedangkan yang mengalami ganguan perilaku/emosional sebanyak juga 2,82 persen, serta yang mengalami kesulitan berbicara adalah sebesar 1,52 persen ${ }^{4}$. Menurut data tersebut jumlah penyandang disabilitas di Indonesia cukup besar tetapi mereka seringkali tidak dipandang keberadaannya. Sampai saat ini mereka masih terus menghadapi berbagai kesulitan berpartisipasi sebagai anggota masyarakat secara utuh dan juga seringkali dilanggar hak asasinya. Penyandang Disabilitas mengalami beragam bentuk pelanggaran HAM. Bentuk pelanggarannya, antara lain, berupa tindakan diskriminasi, stigmatisasi, pelecehan, pengusiran, ejekan-hinaan, penyerangan, pemerkosaan, kekerasan sampai dengan tindakan pembunuhan. Beragam bentuk pelanggaran HAM ini mengakibatkan perendahan harkat dan martabat Penyandang Disabilitas sebagai manusia. Pelaku pelanggaran HAM berasal dari aparat negara, penegak hukum, masyarakat umum, juga terkadang dari keluarganya sendiri ${ }^{5}$.

\footnotetext{
${ }^{4}$ Nuraini, et.al. Profil Penduduk Indonesia Hasil SUPAS 2015 (Jakarta : Badan Pusat Statistik, 2015), hal. 93.

5 Komisi Nasional Hak Asasi Manusia (KOMNASHAM), Mendorong Pengesahan
}

Pada tahun 2011, Indonesia telah meratifikasi Convention On The Rights Of Persons With Disabilities (CRPD) dengan Undang-undang no. 19 tahun 2011 tentang Pengesahan Convention On The Rights Of Persons With Disabilities (Konvensi Mengenai Hak-Hak Penyandang Disabilitas) pada tanggal 18 Oktober 2011. Dari keseluruhan hak yang menjadi hak asasi dari seorang manusia, prinsip HAM dalam CRPD mengakui dan menjamin hak setara bagi semua penyandang disabilitas ${ }^{6}$. Hak ini diatur dalam Pasal 5 yakni mengenai kesetaraan penyandang disabilitas dengan individu lainnya di hadapan hukum dan hak untuk tidak didiskriminasi untuk mendapat perlindungan efektif dan manfaat yang setara dari hukum, serta kesetaraan secara umum $^{7}$. Dalam Pasal 12 CRPD ditegaskan kembali bahwa penyandang disabilitas memiliki hak untuk diakui dimana pun berada sebagai seorang manusia di muka hukum serta memiliki kapasitas hukum

"Optional Protocol to the Convention on the Rights of Persons with Disabilities" dalam Rangka Pemenuhan Hak Asasi Manusia Penyandang Disabilitas, https://www.komnasham.go.id/files/2017030 3-kertas-posisi-komnas- ham-mendorong\$V55ZP0L.pdf, diakses tanggal 10 September 2019 pukul 11.00 WIB

6 Human Rights Watch, Hidup di neraka: Kekerasan terhadap penyandang disabilitas psikososial di Indonesia, Maret 2016.

${ }^{7}$ Untited Nations, Convention on the Rights of Person with Disabilities, 13 Desember 2006, Pasal 5 
atas dasar kesamaan dengan orang lain dengan semua aspek kehidupan.

Namun pada 5 Oktober 2020, DPR dan Presiden resmi menyepakati untuk mengesahkan RUU Cipta Kerja menjadi Undang-Undang No. 11 Tahun 2020. UU Cipta Kerja dibentuk di tengah penolakan besar dari masyarakat. UU Cipta Kerja atau diikenal dengan istilah Omnibus Law ini dinilai memiliki niat yang baik untuk kebutuhan negeri ini dalam sektor pembukaan lapangan kerja dengan mimpi akan adanya investor yang akan datang setelah disahkannya UU ini. Namun disisi lain banyak hal hal yang dilupakan oleh pemerintah, salah satunya adalah hak hak bagi para penyandang disabilitas.

\section{B. Metode Penelitian}

Bentuk penelitian ini adalah yuridis normatif, yaitu dengan menelaah norma hukum tertulis disandingkan dengan pokok permasalahan yang menjadi pembahasan dalam penelitian ini. Data yang digunakan dalam penelitian ini, yaitu data sekunder melalui bahan-bahan kepustakaan, teoriteori yang diambil dari berbagai literatur hukum, UUD Negara Republik Indonesia 1945 serta Peraturan PerundangUndangan.

Peneliti menggunakan alat pengumpulan data berupa studi dokumen dan teori serta peraturan-peraturan yang ada. Metode analisis data yang digunakan dalam mengolah data yang berkaitan dengan penelitian ini adalah metode kualitatif karena pengolahan data tidak dilakukan dengan mengukur data sekunder terkait, tetapi menganalisis secara deskriptif data tersebut. Pada pendekatan kualitatif, tata cara penelitian menghasilkan data deskriptif analitis.

\section{Pembahasan}

\section{Pengertian Hak Asasi Manusia}

Hak Asasi Manusia adalah hak seorang manusia yang sangat asasi yang tidak bisa di intervensi oleh manusia di luar dirinya atau oleh kelompok atau oleh lembaga-lembaga manapun untuk meniadakannya. Hak Asasi Manusia pada hakekatnya telah ada sejak seorang manusia masih berada dalam kandungan ibunya hingga ia lahir dan sepanjang hidupnya hingga pada suatu saat ia meninggal dunia ${ }^{8}$. Pandangan tantang Hak Asasi Manusia juga telah diuraikan John Locke dalam bukunya, dimana manusia itu mempunyai hak untuk hidup (Right of Life), hak untuk kebebasan (Liberty), dan hak untuk memiliki sesuatu (Property)

\footnotetext{
${ }^{8}$ A. Bazar Harahap, Nawangsih Sutardi, Hak Asasi Manusia dan Hukumnya (Jakarta: Perhimpunan Cendekiawan Independen Republik Indonesia, 2007), hlm. 6.
} 
yang tidak dapat diambil oleh siapapun juga. Selain John Locke, Efferson juga mengemukakan pendapatnya tentang Hak Asasi Manusia, yaitu bahwa manusia diciptakan oleh Sang Pencipta (The Creator) memberikan hak kepada manusia yang tidak boleh diambil oleh siapapun juga. Hak itu berupa hak untuk hidup (Right of Life), hak untuk kebebasan (Liberty) dan diikuti dengan adanya tujuan dari hak itu yaitu kesejahteraan bagi manusia. Karena adanya hal-hal tersebut maka terdapatlah persamaan hak (Equality) antara sesama manusia, baik dalam bidang politik maupun hukum ${ }^{9}$.

Di Indonesia melalui Undang-undang Nomor 39 tahun 1999 tentang Hak Asasi Manusia Pasal 1 angka 1 memberikan pengertian mengenai Hak Asasi Manusia $^{10}$.

"Hak Asasi Manusia adalah seperangkat hak yang melekat pada hakikatnya dan keberadaan manusia sebagai makhluk Tuhan Yang Maha Esa dan merupakan anugerah-nya yang wajib di hormati, dijunjung tinggi dan dilindungi oleh negara, hukum, Pemerintah, dan setiap orang demi kehormatan serta perlindungan harkat dan martabat manusia."

\footnotetext{
9 Ibid, h. 9.

${ }^{10}$ Undang-Undang Nomor 39 Tahun 1999 tentang Hak Asasi Manusia, Pasal 1 angka 1.
}

\section{Hukum Hak Asasi Manusia Internasional}

Hukum Internasional pada dasarnya disusun atas dasar prinsip timbal balik, yaitu keberadaan kepentingan yang saling menguntungkan. Pada prinsipnya, sistem ini juga bekerja untuk perlindungan hakhak perorangan. Hukum Hak Asasi Manusia pada pokoknya berhubungan dengan warga negara dari suatu negara, jaringan kewajiban-kewajiban obyektif yang penegakkannya tidak atas dasar kepentingan negara lain serta penegakkannya lebih dilakukan melalui badan-badan internasional seperti $\mathrm{PBB}^{11}$.

Hukum Internasional mengenai Hakhak Asasi Manusia, yang dalam bentuk tertulisnya masih cukup baru (bukan tentang prinsip-prinsip dasarnya) dengan tegas memusatkan fokus pada kepentingan pribadi dan kelompok pribadi, dan yang utama, hubungan mereka dengan pemerintah. Tujuannya ialah memberikan perlindungan internasional untuk hak-hak asasi dan kebebasan pribadi dan kelompok atas penyalahgunaan kekuasaan oleh pemerintah dan dalam hal tertentu juga atas kelakuan pribadi, kelompok dan organisasi swasta lain dan mengusahakan serta menjamin bagi mereka hidup yang

11 Manfred Nowak, Introduction to the Internasional Human Rights Rezim, (Inggris : 2003), hlm.36 
sesuai dengan martabat manusia. Sekaligus diperhatikan kepentingan negara dan juga membantu memulihkan dan/atau memelihara ketentraman sosial dalam masyarakat sendiri dan masyarakat negara lain dengan demikian dapat mencegah timbulnya revolusi dan konflik. Hukum Hak Asasi Manusia ini tidak saja berlaku dalam keadaan damai, tetapi juga dalam situasi konflik bersenjata internasional maupun non-internasional ${ }^{12}$.

\section{Pelanggaran Hak Asasi Manusia}

Apabila membicarakan Hak Asasi Manusia maka akan selalu terkait dengan kekuasaan (power) dan kewenangan (competence). Tanpa mengaitkannya dengan kekuasaan dan kewenangan, maka pembicaraan kita berada di luar konteks Hak Asasi Manusia. Kedua elemen inilah yang menjadi faktor penentu (determinant) dalam menentukan ada tidaknya pelanggaran Hak Asasi Manusia. Tanpa elemen tersebut, maka yang terjadi adalah pelanggaran hukum semata-mata dan tidak termasuk dalam kualifikasi pelanggaran Hak Asasi Manusia. Adapun yang dimaksud kekuasaan disini adalah negara yang dipresentasikan oleh pemerintah yang dilaksanakan melalui aparatur di

\footnotetext{
${ }^{12}$ Peter Baehr, et.al;: Instrument Internasional Pokok Hak-Hak Asasi Manusia (Jakarta: Yayasan Obor Indonesia, 2001), hlm.7-8
}

bawahnya yang memiliki kewenangan tertentu berdasarkan hukum ${ }^{13}$.

Menurut Muladi, pelanggaran Hak Asasi Manusia memiliki nuansa yang khusus, yaitu adanya penyalahgunaan kekuasaan (abuse of power), artinya para pelaku bertindak dalam konteks pemerintahan dan difasilitasi oleh kekuasaan pemerintah (committed within a governmental context and facilitated by governmental power). Perbuatan tersebut dilakukan di dalam atau berkaitan dengan kedudukannya (within or in association with governmental status) ${ }^{14}$.

Masalah pelanggaran Hak Asasi Manusia selalu berkaitan dengan kewajiban negara atau pihak-pihak yang secara hukum berkewajiban untuk melindungi dan menghormati normanorma hukum internasional. Dalam hukum nasional Indonesia melalui UndangUndang Nomor 39 Tahun 1999 tentang Hak Asasi Manusia Pasal 1 angka 6 memberikan definisi mengenai perlanggaran Hak Asasi Manusia ${ }^{15}$, yakni

\footnotetext{
13 H.A Prayitno, et.al., Pendidikan Kebangsaan, Demokrasi dan Hak Asasi Manusia (KADEHAM), (Jakarta : Penerbit Universitas Trisakti, 2003), hlm.142.

14 Muladi, Demokratisasi, Hak Asasi Manusia dan Reformasi Hukum di Indonesia (Jakarta; The Habibie Center 002), hlm. 42

15 Undang-Undang Nomor 39 Tahun 1999 tentang Hak Asasi Manusia Pasal 1 angka 6
} 
"Pelanggaran Hak Asasi Manusia adalah setiap perbuatan seseorang atau kelompok orang yang termasuk aparat negara baik disengaja maupun tidak disengaja atau kelalaian yang secara melawan hukum mengurangi, menghalangi, membatasi dana tau mencabut hak asasi manusia seseorang atau kelompok orang yang dijamin oleh undang-undang ini, dan tidak akan memperoleh penyelesaian hukum yang adil dan benar, berdasarkan mekanisme hukum yang berlaku."

Convention on the Rights of Persons with Disabilities 2006 (CRPD) merupakan konvensi tentang hak-hak penyandang disabilitas sebagai seperangkat instrumen hukum yang mengatur mengenai hak-hak penyandang disabilitas secara spesifik yang diadopsi Majelis Umum PBB pada 13 Desember 2006. Empat tahun kemudian Indonesia telah meratifikasi konvensi tersebut melalui Undang-undang Nomor 19 Tahun 2011 Tentang Pengesahan Konvensi Hak-hak Penyandang Disabilitas pada tanggal 18 Oktober 2011.

CRPD memuat 50 pasal yang menjelaskan hak-hak yang dimiliki oleh penyandang disabilitas dan kewajiban negara dalam pemenuhan hak tersebut. CRPD memiliki tujuan untuk memajukan, melindungi dan menjamin penikmatan hak-hak penyandang disabilitas secara penuh dan setara untuk meningkatkan penghormatan atas martabat yang melekat.

CRPD tidak memuat keberadaan hak baru, yang ada hanyalah mengungkapkan kebaradaan hak-hak yang memuat kebutuhan dan kondisi penyandang disabilitas.

Ada delapan Prinsip yang terdapat dalam CRPD, antara lain:

a) Penghormatan atas martabat yang melekat, otoritas individual termasuk kebebasan untuk membuat pilihan sendiri dan kemandirian setiap orang

b) Non diskriminasi

c) Partisipasi penuh dan elektif, serta keterlibatan dalam masyarakat

d) Penghormatan atas perbedaan dan penerimaan bahwa disabilitas adalah bagian dari keragaman manusia dan kemanusiaan

e) Kesetaraan dan kesempatan

f) Aksesibilitas

g) Kesetaraan antara laki-laki dan perempuan

h) Penghormatan atas perkembangan kapasitas penyandang disabilitas anak dan penghormatan atas hak penyandang disabilitas anak untuk mempertahankan identitas mereka.

Kewajiban negara pihak adalah merealisasikan hak-hak yang termuat dalam CRPD, melalui penyesuaian peraturan perundang-undangan hukum dan administrasi negara termasuk mengubah 
peraturan perundang-undangan, kebiasaan dan praktik yang diskriminatif terhadap penyandang disabilitas, serta pelaksanaan program yang didukung oleh politik anggaran untuk menjamin penyandang disabilitas dalam segala aspek kehidupan antara lain: (1) terkait persamaan dan nondiskriminasi, (2) terkait hak penyandang disabilitas perempuan dan anak, (3) terkait pengakuan di muka hukum, (4) terkait kebebasan dari perlakuan semena-mena, (5) terkait aksesibilitas, (6) terkait hak atas informasi, (7) terkait pendidikan, (8) terkait pekerjaan dan kewirausahaan,(9) terkait hak sipil, politik dan budaya, (10) terkait hubungan dengan negara lain.

Hak bebas dari penyiksaan diatur dalam Pasal 15 CRPD, yang menyatakan bahwa: "No one shall be subjected to torture or to cruel, inhuman or degrading treatment or punishment. In particular, no one shall be subjected without his or her free consent to medical or scientific experimentation." 16

Terkait dengan hak bebas dari penyiksaan, Negara-Negara Pihak wajib secara efektif mengambil Iangkah legislatif, administratif, hukum atau langkah-langkah lain guna mencegah penyandang disabilitas dari tindakan penyiksaan atau perlakuan atau

${ }^{16}$ Convention on The Rights of Persons with Disabilities 2006, Pasal 15 penghukuman kejam, tidak manusiawi, merendahkan martabat manusia atas dasar kesamaan dengan yang lain.

Dalam penjelasan umum disebutkan bahwa Negara Republik Indonesia yang berdasarkan Pancasila dan UndangUndang Dasar Negara Republik Indonesia Tahun 1945 menghormati dan menjunjung tinggi harkat dan martabat manusia. Hak asasi manusia sebagai hak dasar yang secara kodrati melekat pada diri manusia bersifat universal, perlu dilindungi, dihormati, dan dipertahankan, sehingga Pelindungan dan hak asasi manusia juga berlaku terhadap kelompok rentan, khususnya Penyandang Disabilitas ${ }^{17}$.

Pada dasarnya setiap manusia termasuk Penyandang Disabilitas berhak untuk hidup bebas dari penyiksaan sebagaimana yang dimaksud dalam Pasal 28G ayat (2) Undang-Undang Dasar 1945: "Setiap orang berhak untuk bebas dari penyiksaan atau perlakuan semena-mena atau perlakuan yang merendahkan martabat manusia dan berhak memperoleh suaka politik dari negara lain."

Adapun hak tersebut termasuk dalam non-derogable rights yang diatur dalam

\footnotetext{
${ }^{17}$ Undang Undang Dasar 1945, Pasal 28 G ayat (2)
} 
Pasal 28I ayat (1) Undang-Undang Dasar 1945:

"Hak untuk hidup, hak untuk tidak disiksa, hak kemerdekaan pikiran dan hati nurani, hak beragama, hak untuk tidak diperbudak, hak untuk diakui sebagai pribadi dihadapan hukum, dan hak untuk tidak dituntut atas dasar hukum yang berlaku surut adalah hak asasi manusia yang tidak dapat dikurangi dalam keadaan apapun.”

Undang-Undang Nomor 39 Tahun 1999 tentang Hak Asasi Manusia menjadi sangat signifikan terkait penyandang disabilitas karena memperjelas keberadaan penyandang disabilitas sebagai bagian dari kelompok rentan bersamaan dengan kelompok-kelompok lain. Pasal 5 ayat (1) Undang- Undang Nomor 39 Tahun 1999 Tentang Hak Asasi Manusia menyatakan secara tegas bahwa setiap orang yang masuk dalam kategori kelompok rentan, maka ia memperoleh perlakuan dan perlindungan khusus. Dalam penjelasan atas Undang-Undang tersebut, mereka yang dikategorisasikan sebagai kelompok rentan adalah orang lanjut usia, anak-anak, wanita hamil, fakir miskin, dan penyandang disabilitas.

Isi dari pasal diatas secara lugas menyatakan pengakuan atas penyandang disabilitas sebagai sebuah kelompok yang wajib dilindungi dan diperlakukan secara khusus tidak terkecuali dalam berbagai program dan kebijakan.
Hak bebas dari penyiksaan diatur secara khusus dalam Pasal 33 UndangUndang Nomor 39 Tahun 1999 tentang Hak Asasi Manusia menegaskan bahwa :

"Setiap orang berhak untuk bebas dari penyiksaan, penghukuman atau perlakuan yang kejam, tidak manusiawi, merendahkan derajat dan martabat kemanusiaannya." Dalam Pasal 8 dan 71 Undang-Undang Nomor 39 Tahun 1999 tentang Hak Asasi Manusia menegaskan bahwa Perlindungan, pemajuan, penegakkan dan Pemenuhan hak Penyandang Disabilitas merupakan tanggung jawab negara. Pemerintah juga wajib bertanggung jawab menghormati, melindungi, menegakkan dan memajukan hak asasi manusia yang diatur dalam Undang-Undang ini, peraturan perundang- undangan lain dan hukum internasional tentang hak asasi manusia yang diterima oleh negara Republik Indonesia”.

\section{Undang-Undang Nomor 8 Tahun} 2016 tentang Penyandang Disabilitas telah disahkan dan diundangkan. Secara umum Undang-Undang ini telah memuat sejumlah tuntutan yang selama ini diperjuangkan oleh para penyandang disabilitas di Indonesia. Undang-Undang ini lebih baik karena tidak lagi berbasis pada belas kasihan (charity) tapi sudah berbasi pada hak (rights). ${ }^{18}$

\footnotetext{
${ }^{18}$ Yossa AP Nainggolan, et.al. Rekam Jejak Kontribusi KOMNAS HAM Dalam Pembentukan Undang- Undang No.8 Tahun 2016 Tentang Penuandang Disabilitas (Jakarta: Komnas HAM, 2016), hlm. 75.
} 
Hak-hak Penyandang disabilitas terkait dengan hak untuk tidak disiksa telah diatur di dalam pasal-pasal antara lain : Pasal 6 Undang-Undang Nomor 8 Tahun 2016 tentang Penyandang Disabilitas menyatakan bahwa $:^{19}$

"Hak hidup untuk penyandang disablitas meliputi hak:

a) Atas Penghormatan integritas

b) Tidak dirampas nyawanya

c) Mendapatkan perawatan dan pengasuhan yang menjamin kelangsungan hidupnya

d) Bebas dari penelantaran, pemasungan, pengurungan, dan pengucilan

e) Bebas dari ancaman dan berbagai bentuk eksploitasi

f) Bebas dari penyiksaan, perlakuan dan penghukuman lain yang kejam, tidak manusiawi, dan merendahkan martabat manusia."

Pasal 26 Undang-Undang Nomor 8 Tahun 2016 tentang Penyandang Disabilitas bahwa ${ }^{20}$ :

"Hak bebas dari Diskriminasi, penelantaran, penyiksaan, dan eksploitasi untuk Penyandang Disabilitas meliputi hak:

a) Bersosialisasi dan berinteraksi dalam kehidupan berkeluarga, bermasyarakat, dan bernegara tanpa rasa takut; dan

b) Mendapatkan Pelindungan dari segala bentuk kekerasan fisik, psikis, ekonomi, dan seksual."

\footnotetext{
${ }^{19}$ Undang-Undang No. 8 Tahun 2016 tentang Penyandang Disabilitas. Pasal 6

${ }^{20}$ Undang-Undang No. 8 Tahun 2016 tentang Penyandang Disabilitas. Pasal 26
}

\section{Penyandang Disabilitas \& UU Cipta Kerja}

Berdasarkan uraian diatas kita mengetahui banyak hal-hal yang menjadi hak bagi para penyandang disabilitas dan kewajiban negara untuk melindungi dan memfasilitasi para penyandang disabilitas. Namun pada fakta yang tertera di UU No. 11 Tahun 2020 Tentang Cipta Kerja terdapat dua poin yang menjadi perhatian, yaitu :

a) Pasal 154A huruf 1 UU Nomor 13 Tahun 2003 tentang Ketenagakerjaan, yang menyatakan bahwa "Pemutusan hubungan kerja dapat terjadi karena alasan : 1. pekerja/buruh mengalami sakit berkepanjangan atau cacat akibat kecelakaan kerja dan tidak dapat melakukan pekerjaannya setelah melampaui batas 12 bulan".

b) Menghapus Pasal 27 ayat (2) UndangUndang Nomor 28 Tahun 2002 tentang Bangunan Gedung yang mengatur persyaratan kemudahan hubungan ke, dari, dan di dalam bangunan gedung berupa aksesibilitas bagi penyandang Disabilitas dan lanjut usia.

Apabila kita teliti dalam poin :

a) Dalam UU Ketenagakerjaan (13/2003) sebelumnya tidak diatur terkait hal hal 
spesifik yang dapat menyebabkan seseorang di PHK. Tentu hal ini menjadi pertanyaan bagii para penyandang diisabilitas munculnya pasal ini. Dengan munculnya pasal ini tentu tidak mewakilii semangat dari UU No 8 Tahun 2016 Tentang Penyandang Disabilitas dan Convention on the Rights of Persons with Disabilities 2006 (CRPD) yang dimana seharusnya negara melindungi penyandang disabiltas dari diskriminasi pasal ini.

b) Dengan dihapusnya Pasal 27 ayat (2) UU Bangunan Gedung, maka UU Cipta Kerja justru tidak mendukung pemenuhan hak penyandang Disabilitas dalam mendapatkan akomodasi yang layak dalam dunia kerja. UU Cipta Kerja tidak mencantumkan ketentuan kuota $1 \%$ bagi perusahaan swasta dan $2 \%$ bagi BUMN/BUMD dan

Pemerintah/Pemerintah Daerah untuk mempekerjakan penyandang

Disabilitas dari keseluruhan pegawai, yang saat ini tercantum dalam UU Penyandang Disabilitas.

Perlu catatan juga bahwa UU Cipta Kerja tidak mengatur mekanisme pencegahan dan perlindungan kekerasan terhadap pekerja perempuan khususnya perempuan penyandang Disabilitas. Dapat disimpulkan bahwa dengan disahkannya UU No. 11 Tahun 2020 tentang Cipta Kerja ini maka sudah terjadi "Pelanggaran Hak Asasi Manusia" oleh negara baik by commission maupun by omission, dapat dilihat dari kegagalan negara dalam memenuhi empat jenis kewajiban yang berbeda, antara lain:

a. Kewajiban untuk menghormati (the obligation to respect)

Menghormati merupakan tindakan atau sikap atau perilaku yang mengakomodasi, membiarkan atau membolehkan nilai kepentingan, keberadaan seseorang atau kelompok orang untuk tumbuh dan berkembang serta beraktivitas secara leluasa dan wajar dalam segala aspek kehidupan berbangsa, bernegara dan bermasyarakat. $^{21}$ Kewajiban ini menuntut negara dan agen atau aparaturnya untuk tidak pernah melakukan tindakan yang dapat melanggar integritas individuatau kelompok atau pelanggaran atas kebebasan mereka. ${ }^{22}$

\footnotetext{
${ }^{21}$ Saharudin Daming. Marjinalisasi Hak Politik Penyandang Disabilitas.(Jakarta : Komnas HAM, 2011), hlm.67

${ }^{22}$ Mahrus Ali, Syarif Nurhidayat, Penyelesaian Pelanggaran HAM Berat (In Court System dan Out Court System), (Depok : Gramata Publishing, 2011), hlm.17
} 
b. Kewajiban untuk melindungi (the obligation to protect)

Melindungi adalah tindakan atau sikap atau perilaku yang mencegah atau membentengi suatu komunitas melalui perangkat hukum yang menjamin semua pihak untuk tidak melakukan hal-hal yang dapat mengurangi, membatasi, mempersulit mengganggu atau menghambat atau menghilangkan secara sewenangwenang hak seorang untuk berperan/berpartisipasi atau menikmati nilai kemanfaatan publik. ${ }^{23}$

Kewajiban ini menuntut negara dan agen atau aparatnya melakukan segala tindakan yang ditujukan dalam rangka melindungi warga individu maupun kelompok serta mencegah terjadinya pelanggaran Hak Asasi Manusia terhadap mereka oleh pihak lain. $^{24}$

c. Kewajiban untuk memenuhi (the obligation to fulfil)

Memenuhi atau melaksanakan adalah tindakan, sikap atau perilaku yang mewujudkan, mengimplementasikan sebagian atau seluruh unsur-unsur hak seseorang atau sekelompok orang untuk

\footnotetext{
${ }^{23}$ Saharudin Daming, Op Cit, h.67

${ }^{24}$ Mahrus Ali, Syarif Nurhidayat, Op Cit h.17
}

berperan atau berpartisipasi atau menikmati nilai kemanfaatan publik. ${ }^{25}$ Kewajiban ini menuntut negara untuk melakukan tindakan yang memadai dalam memberikan peluang secara yuridis kepada semua pihak sebagai warga negaranya, untuk mencapai kepuasan bagi yang memerlukan yang kebutuhan tersebut tidak dapat dipenuhi oleh upaya pribadi seperti mengambil langkah legislatif, administratif, yudisial dan kebijakan praktis. $^{26}$

d. Kewajiban untuk mengembangkan /meningkatkan

Kewajiban ini menuntut negara untuk meningkatkan kesadaran masyarakat akan hak-hak dasar yang mereka miliki sampai pada pemahaman mekanisme penegakannya. ${ }^{27}$

\section{Kesimpulan}

Berdasarkan hal-hal yang sudah dipaparkan diatas bahwa UU No. 11 Tahun 2020 tentang Cipta Kerja sudah melanggar hak bagi para penyandang disabiltas, dan kegagalan negara dalam melindungi hak tersebut. Oleh karena

\footnotetext{
${ }^{25}$ Saharudin Daming, Op Cit h.67

${ }^{26}$ Mahrus Ali, Syarif Nurhidayat, Op Cit, h.17

${ }^{27}$ Ibid, h. 18
} 
terdapat beberapa Langkah yang dapat dilakukan oleh pemerintah atau masyarakat terkait isu ini diantaranya melakukan judicial review ke Mahkamah Konstitusi, dikeluarkan Peraturan Pemerintah (PP) terkait hak-hak penyandang disabilitas dalam UU No. 11 Tahun 2020 tentang Cipta Kerja dan mendesak Pemerintah dan DPR untuk mempublikasikan materi-materi terkait dengan UU No. 11 tahun 2020 tentang Cipta Kerja yang aksesibel, baik audio maupun visual, bagi penyandang disabilitas.

\section{Daftar Pustaka}

\section{Buku}

A. Bazar Harahap, Nawangsih Sutardi, Hak Asasi Manusia dan Hukumnya, Jakarta : Perhimpunan Cendekiawan Independen Republik Indonesia, 2007

Mahrus Ali, Syarif Nurhidayat, Penyelesaian Pelanggaran HAM Berat (In Court System dan Out Court System), Depok : Gramata Publishing, 2011

Peter Baehr, et.al;: Instrument Internasional Pokok Hak-Hak Asasi Manusia; Jakarta : Yayasan Obor Indonesia, 2001

H.A Prayitno, et.al., Pendidikan Kebangsaan, Demokrasi dan Hak Asasi Manusia (KADEHAM), Jakarta : Penerbit Universitas Trisakti, 2003

Rhona K.M. Smith et al., Hukum Hak Asasi Manusia, cet 1, Yogyakarta:
Pusat Studi Hak Asasi Manusia Universitas Islam Indonesia, 2000.

\section{Karya Ilmiah}

Human Rights Watch, "Hidup di neraka: Kekerasan terhadap penyandang disabilitas psikososial di Indonesia, Maret 2016

Manfred Nowak, Introduction to the Internasional Human Rights Rezim

Muladi, Demokratisasi, Hak Asasi Manusia dan Reformasi Hukum di Indonesia, Jakarta : The Habibie Center 002

Nuraini, et.al. Profil Penduduk Indonesia Hasil SUPAS 2015, Jakarta : Badan Pusat Statistik, 2015

Saharudin, Daming. Marjinalisasi Hak Politik Penyandang Disabilitas, Jakarta : Komnas HAM, 2011

Yossa AP Nainggolan, et.al. Rekam Jejak Kontribusi KOMNAS HAM Dalam Pembentukan Undang- Undang No.8 Tahun 2016 Tentang Penuandang Disabilitas.

\section{Peraturan Perundang - Undangan}

Undang-Undang Dasar Republik Indonesia Tahun 1945

Undang- Undang Nomor 39 Tahun 1999 Tentang Hak Asasi Manusia

Undang-Undang Noor 8 Tahun 2016 tentang Penyandang Disabilitas

Convention on The Rights of Persons with Disabilities 2006 


\section{Website}

Komisi Nasional Hak Asasi Manusia (KOMNASHAM), Mendorong Pengesahan "Optional Protocol to the Convention on the Rights of Persons with Disabilities" dalam Rangka Pemenuhan Hak Asasi Manusia Penyandang Disabilitas, https://www.komnasham.go.id/files/ 20170303-kertas-posisi-komnasham-mendorong-\$V55ZP0L.pdf, diakses tanggal 10 September 2019 pukul 11.00 WIB

United Nations Economic and Social Comission for Asia and the Pacific, "Overview" http://www.unescapsdd.org/disabilit y/overview. diakses tanggal 20 Agustus 2019 pukul 15.20 WIB 